\title{
HOTS-ORIENTED INDONESIAN LANGUAGE LEARNING IN SENIOR HIGH SCHOOL IN JAMBI
}

\author{
Rustam, Rasdawita, Priyanto \\ Department of Indonesian Language Education and Literature, \\ Faculty of Teacher Training and Educational Sciences, Universitas Jambi, Indonesia \\ Jalan Raya Jambi-Ma, Bulian KM.15, Mendalo Darat, Jambi, Indonesia \\ Corresponding Author: rustam@unja.ac.id
}

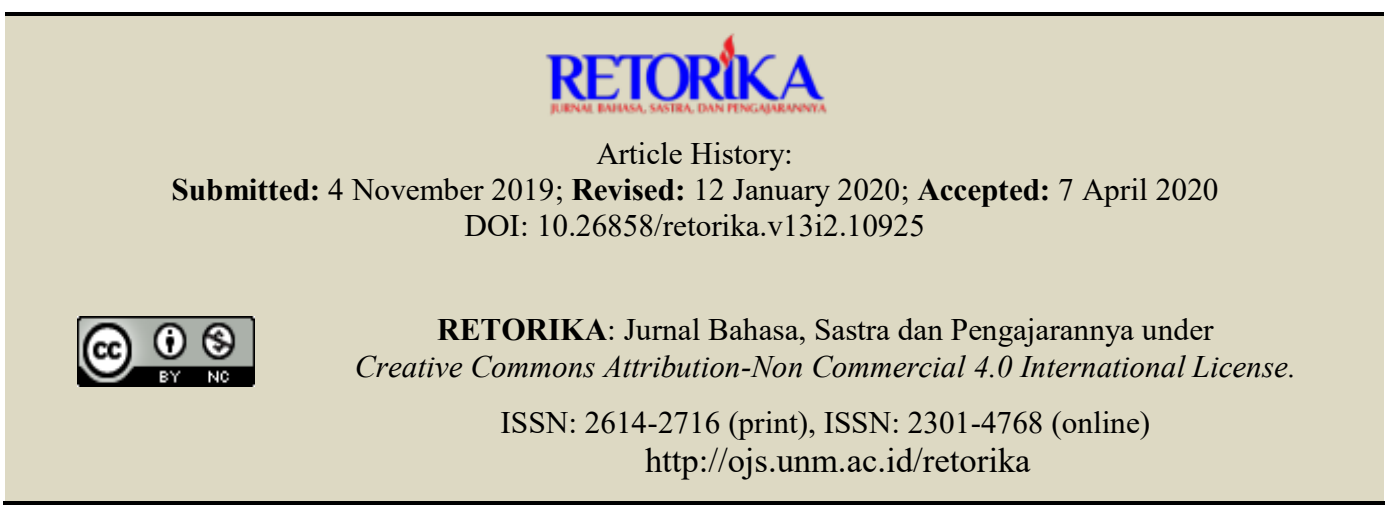

\begin{abstract}
The purpose of this research was to describe the competence of the high school teachers in Jambi in designing, implementing, and evaluating HOTS-oriented Indonesian Language learning. To answer this question, the concept of Indonesian Language learning was employed. This study used a qualitative design with case study technique. The data were comprised of the responses, learning process, and action conducted by the teachers. The respondents were selected using purposive sampling method by considering teacher's academic qualifications. Data collection was performed through interview accompanied by focused group discussion (FGD), observation and document-ation. The results of this study showed that the Indonesian Language teachers had designed, implemented and evaluated students' performance in HOTS-oriented Indonesian Language learning. Unfortunately, the teachers were less capable of synergizing the HOTS-oriented learning with pedagogical approaches, such as genre-based (text learning), scientific learning and CLIL.
\end{abstract}

Keywords: learning, Indonesian, HOTS

Problems that often arise in the Indonesian Language classrooms, especially in terms of implementing the learning process in accordance with education standards in schools are that the teachers' poor understanding and mastery of the Core Competencies (KI), Basic competencies (KD), and Learning Achievement Indicators (GPA) in the 2013 curriculum that is oriented to Higher Order Thinking Skills (HOTS). Learning models that are oriented to HOTS are associated with thinking skills in the cognitive, affective, and psychomotor domains that are a unity in the learning process. The cognitive domain contains factual, conceptual, procedural and metacognitive knowledge, while the affective domain is associated with attitudes, values, feelings, emotions and the degree of acceptance or rejection of an object in learning activities. The affective domain is di- 
vided into five categories, namely, acceptance, responding, evaluating, managing, and characterizing (Direktorat GTK, 2018).

The psychomotor domain involves students in doing something through physical motor movements that consist of reflexes, basic movements, perceptive, precision, expressive, and interperative. The competencies needed in the millennial or 21 st century include critical thinking skills, communication skills, cooperative skills, and problem-solving skills.

Dealing with this issue, it is necessary to examine taecher's competency in designing learning that reflects the integration of HOTS into the curriculum content. This can be studied in depth through collective case studies (Creswell, 2009), that are by examining a number of cases simultaneously so that the results can depict how teachers design, implement, and evaluate student performance as a whole to achieve the 2013 curriculum and 21 st century Indonesian education goals.

The implementation of Indonesian Language learning in high school is a synthesis of genre, scientific pedagogy, and Content and Language Integrated Learning (CLIL). The primary model used in the scheme is the pedagogical genre with 4M (Context Building, Model Analysis, Guided Construction, and Independent Construction). Knowledge (KD-3) is acquired through the $5 \mathrm{M}$ scientific approach (Observing, Questioning, Gathering Information, Reasoning, and Communicating). Skills development (KD-4) is achieved by carrying out the steps of guided construction and independent construction. The CLIL approach is used to enrich learning with the following principles: (1) text content is a model or a task containing character and knowledge development as a world citizen or a nation citizen; (2) com-munication is an important element to state vari-ous language goals in life; (3) every text has different cognition structures that needs to be acknowledge for the sake of effective communication; (4) culture, communication language must involve ethics, language politeness and international, national, or local culture (Dirjen PSMA, 2017).

The development of Higher-order thinking skills or HOTS is affected by several factors: (a) a particular learning situation that requires specific learning strategies that cannot be applied in every situation; (b) intelligence that is no longer seen as an irreversible competency, but rather the unity of knowledge which is influenced by learning environment, strategy and awareness in learning; (c) the shift in the concept of learning that is from unidimensional, linear, hierarchical or spiral towards multidimensional and interactive; and (d) reasoning, analytical skills, problem solving, and critical and creative thinking skills (Aryana, 2018).

The improvement of higher order thinking skills (HOTS) as Transfer of Knowledge is associated with the improvement in the cognitive, affective, and psychomotor domains as a unity in the text-based learning process. The cognitive domain in question is the ability to repeat or restate concepts or principles that have been learned in the learning process. This activity is related to the ability to think, develop, recognize, understand, conceptualize, determine knowledge as well as perform reasoning (Mahsum, 2014). Indonesian Language learning requires the teachers to take advantage of high-level questions. Quality questions are expected to promote critical thinking and creativity in students (Rurisfiani, Ramly, \& Sultan, 2019). HOTS-oriented learning occurs when students are involved in active learning that encourage them to be able to change or create knowledge, and produce some-thing new, (Dinni, H. N., 2018). Furthermore, the results of the research related to the application of HOTS conducted by Pamungkas, N. A. R. (2019) showed that the application of HOTS-based learning could improve students' ability to answer questions from a text that demands the ability to analyze, evaluate, and create. The results of the study above suggest that HOTS-oriented learning can be applied by considering the situation, conditions, and character of the students.

This study focused on how the Indonesian Language teachers applied HOTS-oriented learning in high school. It specifically described the competence of the Indonesian Language teachers in Jambi in designing and implementing HOTSoriented learning as well as in evaluating student performance in HOTS-oriented learning.

\section{METHOD}

This research used a qualitative case study design that focused more on questions about the case being learned (Creswell, 2009; Lincoln, 1997). The case being studied was the learning 
process conducted in the Indonesian Language classrooms in high school in Jambi. This study was conducted in three public and one private senior high schools under the supervision of the Ministry of Education and Culture of the Jambi Province. There were eight Indonesian language teachers involved in this study. They were selected based on the participant eligibility cri-teria by means of purposive sampling.

The first observation was conducted by the researchers. It was a direct observation where the researchers visited the participated schools to observe the teachers' and students' behavior, learning activities (both inside and outside the classroom). Then, interviews were conducted face to face with the participants through Focus Group Discussion (FGD) to obtain more accurate information. FGD was also conducted to help elicit the issues related to the teachers' competencies in developing learning tools (syllabus and lesson plans).

The third step was to perform a documentation study to describe the qualitative data indepth (Creswell, 2009). The data analysis was an ongoing process that required reflection on data, analytical questions, and writing brief notes throughout the study. The steps of data analysis in this research included: (a) categorizing the information correctly (open coding), (b) selecting one category and placing it in a theoretical model (axial coding), for example how the teachers designed a lesson plan, (c) describing narrative forms based on the relationship between cases (selective coding) (Norman K. \& Tvona S. Lincoln, 2009). In data coding, it was necessary to consider: (a) a general understanding of the data, (b) the ideas that were written in the form of understanding basic meanings, (c) combining the same themes/topics into more detailed and related ones, (d) assigning a code into a segment or category, (e) creating one sentence/ clause/ phra$\mathrm{se} /$ word that was appropriate to describe the topic; (f) summarizing the category and make the right code, $(\mathrm{g})$ inserting the data into categories for initial analysis, and (h) re-coding the existing data (Yin, 2003; Wooside, 2010).

In detail, data analysis was performed by: (1) validating the accuracy of information from the participants (Indonesian language teachers), (2) interpreting themes or descriptions (HOTS learning), (3) connecting the themes or descriptions, (4) coding the data manually, (5) reading the data, (6) processing and preparing the data for analysis, and (7) analyzing the raw data (transcripts, field data) (Creswell, 2009).

\section{FINDINGS AND DISCUSSION}

\section{Findings}

\section{Designing the HOTS-Oriented Indonesian Language Learning}

The field data showed that the Indonesian language teachers designed HOTS-oriented Indonesian language learning by first understanding the Competency Standards (SKL) and Core Competencies (KI) of the subject. KI includes: spiritual attitudes, social attitudes, knowledge, and skills that function as the integration of learning content, subjects or programs in achieving SKL. KI is designed for all classes because KI is associated with $\mathrm{KD}$ inter-class lessons. This is in line the following excerpt of interview:

(G1, XVS) "we need to understand and analyze the SKL and how KI is formulated to support achieve the SKL. Core Competencies (KI) have three domain achievements, namely social core competency (KI-2) including spiritual attitude (KI-1), knowledge (KI-3), and skills (KI-4). Basic Competency $(\mathrm{KD})$ is the ability required to achieve KI. Basic Competency requires students to think and act, represented by operational verbs and relevant materials".

Before developing lesson plans, the teachers had to understand the Competency Achievement Indicators (GPA) of the lesson. Teachers' understanding of the relationship between SKL, $\mathrm{KI}$, and KD can help them set appropriate GPA to be achieved. The Indonesian language teachers were able formulate GPA related to the cognitive domain, psychomotor and abstract and concrete thinking skills. To formulate GPA, the teachers must pay attention to: (1) the students' thinking process to achieve the minimum requirement of $\mathrm{KD}$; (2) the use of operational verbs that can be measured; (3) the formulation of simple, clear, and understandable sentences; (4) the use of unambiguous words; (5) one action to describe each GPA; (6) the characteristics of the subjects, potential and needs of the students, schools, communities, and environment. This is in accordance with the following excerpt of interview. 
(G3, SMA1) "Before formulating a GPA, we must focus on determining what thought processes exist in $\mathrm{KD}$, using operational words in accordance with Bloom's taxonomy, that consists of analyzing (C4), evaluating (C5), and creating (C6) that reflects (HOTS), and the students' needs".

The next step to do was to categorize the Competency Achievement Indicator (CPI) into the criteria of Urgency, Relation, Relevance, Usability (UKRK). The required competencies were the minimum competencies found in KD. The goal was to measure the achievement of the minimum standards of KD. These were included in the lesson plan and actualized in the implementation of the learning process so that KD can be achieved. The operational verbs in IPK must be designed by referring to HOTS, for example asking the students to analyze and categorize important parts of the information observed from sociocultural phenomena. The Operational Verbs (KKO) define information categories and determine the focus of the informant. Students' competencies can be described using the operat-ional verbs organize, discover coherence, and construct information categories. Students' competencies in locating the main idea or the writer's bias and value can be describe using the verbs label or provide. These concepts were implemented by the teachers in designing the lesson plan, described as follows.

(G2, SMA4) "in compiling competency achievement indicators, we must pay attention to operational verbs that characterize or bring up Higher Order Thinking Skills (HOTS), for example: the verb 'analyze' in KD3 class $\mathrm{X}$, then the material also illustrates the elements of analysis negotiating text structure and language aspects using persuasive sentences. Furthermore, KD4 uses the word "construct" to construct the text of the negotiation observation text report by steps: selecting a topic, arranging a framework, developing the framework into texts, and writing or creating negotiating texts".

(G2, SMA1) "in designing lesson plans on KD3 learning for example: analyzing the structure (orientation, offer, approval, and closing) and the language of negotiating texts by paying attention to HOTS with the steps: first, students collect information on model text by examining video clips of negotiation events; second, students study the content of the negotiating text based on its structural components (orientation, submission, bidding, approval, closing); third, students identify the structure of the negotiating text over its structural components (orientation, submission, bidding, approval, closing); fourth, students analyze the language of the negotiating text to find pairs of speeches in the negotiating text; fifth, students analyze the language of the negotiating text to find persuasive sentences in the negotiating text; sixth, students determine the topic of negotiating texts with mind maps; seventh, students draw up a negotiating text framework; eighth, students collect information that is in accordance with the topic chosen; ninth, students compile negotiating texts based on the prepared framework by paying attention to the structure, content, and linguistic elements of the text".

\section{Implementing the HOTS-Oriented Learning Design}

\section{Pre-Activities}

The opening activities started with an orientation such as greeting and praying, checking student attendance and disciplinary attitudes, and providing motivation. Pre-activities also included checking the students' readiness, available learning tools and media. Greeting and praying together reflect religious values, checking on student attendance and motivating the students reflect nationalism, independence, and integrity.

In the beginning of the lesson, the teacher delivered the basic competencies and learning objectives to be achived. The teacher helped the students connect their prior knowledge to what will be learned that day. The teacher outlined materials to be studied and planned activities. The teacher then provided an explanation of the tasks and assignment that should be done. In pre-learning activitie, the teacher delivered the bene-fits of learning in everyday life contexts.

\section{Whilst Activities}

The activities carried out at this stage were as follows: (1) Building the context, meaning the teacher oriented the students to the problem being studied by asking questions, making statements, making problems, making research projects, ask- 
ing an issue, showing conversational vide and life phenomena; (2) the teacher then divided the students into several groups of 3-5 based on gen-der, race, characteristics of heterogeneous stud-ents as to build the value of togetherness; (3) the students critically took scientific steps (observ-ing, asking, reasoning, evaluating, and communi-cating) about the things being learned; (4) the teacher coordinated the students in learning by letting them to work together in groups to critic-ally identify problems related to the content and structure of the text, the students critically provided responses and opinions on problems related to the content and structure of the text; (5) the teacher guided the students by facilitating and providing guidance to work together in group discussion (phenomena, series of events, and reviews, etc.). This finding is in line with the following excerpt of interview.

(G1, SMA1) "To begin with, the teacher must provide a real factual experience for the students' in the form of questions in context-building activities through the media".

Conceptual knowledge includes: classification and category knowledge including specific categories, classes, divisions, and arrangements used in different subjects, principles and generalizations that tend to dominate an academic discipline and it is used to study phenomena or solve problems in scientific disciplines. Whereas procedural knowledge, namely, completing exercises are routine enough to solve new problems. Conceptual and procedural knowledge are also used by the teacher in implementing learning material, for example:

(G2, CK) "KD from KI-4 in class XI, students are able to write complex explanatory texts (genre pedagogy) by observing, collecting data, analyzing data, and making texts (HOTS) based on scientific conceptual and procedural knowledge (scientific)".

Metacognitive knowledge is related with knowledge of awareness in general as well as awareness and knowledge about one's personal awareness. Students must be more aware and responsible for their own knowledge and thinking. Students will become more aware of their own thoughts as well as more they know awareness in general, and when they act in this awareness, they will tend to learn better. It has been implemented by the teacher in class learning, for example:

(G2, SMA3) "The teacher asks questions to encourage thinking from inferential questions, interpretive questions, transfer questions and hypothetical questions, as a means of delivering students in the learning process for their metacognitive learning experiences".

Likewise with self-knowledge or selfawareness regarding the broadness of the basis of self-knowledge is an important aspect of selfknowledge. Students need to pay attention to different types of strategies. A individual's awareness tends to be too dependent on certain strategies, in which there are more appropriate other strategies for the task so then it can lead to a change in the use of strategies in learning.

For affective domain skills (acceptance, responding, rating, managing, and characterizing). The affective domain is related to attitudes, values, feelings, emotions and the degree of acceptance or rejection of an object in learning activities and the affective domain divides into five categories, such as the acceptance of a kind of sensitivity in receiving stimuli or stimulation from outside that comes to students; responding to an attitude that shows active participation to involve in a particular situation and reacting to it in one way; provide value, having a appreciation and trust in a particular symptom or stimulus; managing the conceptualization of values into a value system, as well as the stabilization and priority of values that have been held; and the characterization of the integration of all the value systems in which students have had affect their personality patterns and behavior.

Psychomotor domain skills (imitation, manipulation, precision, articulation, and naturalization). Psychomotor process skills are skills in doing work by involving the physical movements (motor) and it consists of reflex movements, skills in basic, perceptual, accuracy, complex skills, expressive and interperative skills. Imitation means imitating individual's act of manipulating means doing a skill or producing a product by following general instructions, it is not based on observation. Precision means independently carrying out skills or producing products with accuracy, proportion, and accuracy. In everyday language, this category is stated as "advanced level". Articulation is modifying a skill or product 
to fit a new situation, or combining more than one skill in a harmonious and consistent order. Naturalization means completing one or more skills easily and making automatic skills with existing physical or mental energy. In this category, the nature of activities has been automatic, conscious mastery of activities, and mastery of related skills already at the strategic level.

(G1, SMA4) "In text learning, there are text modeling activities or studying texts, students are skilled in grouping and finding negotiating text characteristics, for example. The aim of this activity is that students gain knowledge about negotiating texts independently with the help of teachers and are done in groups and in pairs by demonstrating imitation behavior, manipulation, precision, articulation, and naturalization".

Furthermore, the teacher Modelling the text, it is intended to the teacher provides concepts, phenomena, data, facts, events and so on it is related to the text material will be studied. In modeling the text, the teacher must pay attention to class levels, semesters, KI, KD, GPA, and Operational Working Words (KKO) as well as the purpose of text learning; teachers must also consider the duration of time, the media, tools that are used effectively; then using HOTS-oriented learning achievement outcomes (analyzing, evaluating, and creating/ C4, C5, and C6) Blom's taxonomy.

Furthermore, Writing Guided Text, it means that the teacher conducts coaching in groups/in writing text by: (1) students work together in groups preparing reports on the results of discussions relating to critically identifying the contents of the text including identification of phenomena, series of events, and reviews determining together the contents texts including the purpose of identifying phenomena, sequence of events, and commentary; analyze critically toward the contents of the text including identification of phenomena, sequence of events, and commentary; determine together in the explanatory text structure group which includes identification of phenomena, sequence of events, and commentary; analyze critically on text structure including the identification of phenomena, sequence of events, and commentary; and students present confidently on the results of group discussions; (2) analyze and evaluate the problem solving process by: students critically evaluate or respond to the presentation of the results of other group discussions, working together to improve the results of the discussion based on input/ suggestions from other groups; (3) Passing the text in a guided manner, ie students are guided in working groups in determining the topic/ title of the text that is appropriate in accordance with the results of the analysis of text content, students are guided by the teacher work together to develop the topic in the form of a text framework with a mind map.

The final step in writing text is Constructing Text Independently by conducting independent and creative activities to set the topic then develop it in the form of a text framework by paying attention to the results of the analysis of the contents and structure of the text.

(G1, SMA3) "In HOTS-oriented text learning activities writing texts in groups needs to critically identify the contents of the text including the identification of phenomena, sequences of events, and reviews to determine together the contents of the text including the purpose of identifying phenomena, sequences of events, and reviews of the text".

(G1, SMA1) "In writing independently oriented creative or creative text activities also need to be considered productive and critical thinking, namely accuracy, clarity, open thinking, putting yourself in the right situation".

\section{Post-Activities}

Post activities included the activity of summarizing or reflecting on learning. Second, the students critically responded to feedback given by the teacher. Third, students earnestly carry out assessments conducted by the teacher, fourthly, students earnestly respond to the assign-ments given by the teacher. Fourth, students critically respond to information from the teacher about planned learning activities for the next meeting. Fifth, students earnestly respond. The activity has been carried out by the teacher as illustrated in the following data.

(G1, SMA1) "to close the ideal learning we must do a number of things including raising students' responsive actions in making a summary/ conclusion or reflection on learning; carry out the assessment properly; sin- 
cerely respond to the assignments given by the teacher".

\section{Evaluating HOTS-Oriented on Student Learn- ing Outcomes}

The attitude assessment conducted by the teacher is able to develop students in a religious attitude on the core competency of KI-1, which is to respect and appreciate the religion they hold. Furthermore, the development of social attitudes that refers to KI-2, namely respecting and living honest, disciplined, responsible, caring, polite, confident, and interacting socially with the environment. Attitude assessment techniques can be done by teachers through observation, interviews, daily journal. The implementation of the assessment is done by the teacher during the learning process which is oriented towards higher-order thinking (HOTS). Correspondingly, the Indonesian language teacher has taken the following actions,

(G2, SMA3) "by helping students to obtain declarative knowledge by instructing, storing, developing procedural knowledge by internalizing it in the lives of students; and expanding and capturing knowledge by comparing, classifying, constructing, and analyzing; and use knowledge meaningfully by making decisions, solving problems and finding in learning".

Attitude assessment serves to detect students who need to get attitude coaching based on negative attitude notes. Coaching is done to improve attitudes recorded turtle or negative until students have good behavior. In addition, teachers can also use peer assessment formats. This assessment asks students to find positive and negative attitude from their peers. The instrument used was self-assessment among friends in class. Self-assessment and peer-to-peer functions as a means of confirmation of the teacher's assessment. Assessment between friends is best done when students are doing group activities. Interfriend assessment instruments can be in the form of inter-friend assessment sheets contain items are expected about positive attitude statement.

(G1, SMA4) "Conducts an assessment of students 'attitudes during the learning process by making journal assessment of attitude, for example, numbers, names of students' expected behavior, attitudes that emerge and does not continue. Then, it is done by the peer assessment. All of these attitude values are reflections of character originated from local culture".

Knowledge and skills assessment (BC from KI-3 and KI-4) is done by measuring students' mastery which includes dimensions of factual, conceptual, procedural and metacognitive knowledge at various levels of the thought process. The knowledge assessment procedure starts from the preparation of the plan, the development of the appraisal instrument, the implementation of the appraisal, the processing and reporting, and the use of the results of the appraisal. Knowledge assessment techniques use written, oral, and assignment tests. Assessment of learning outcomes is expected to help students to improve higher order thinking skills/ HOTS, because higher level thinking can encourage students to think broadly and deeply about subject matter.

HOTS questions are measurement instruments used to measure higher-order thinking skills, namely the ability to think that is not just a recall, restate, or refer without doing processing (recite). HOTS questions in the context of the assessment measure the ability of: (1) transferring one concept to another, (2) processing and applying information, (3) looking for links from different kinds of information, (4) using information to solve problems, and (5) analyzing ideas and information critically. However, HOTSbased questions do not mean questions that are more difficult than recall questions.

(G2, SMA1) "In the knowledge of student learning outcomes must refer to learning experiences that are able to transform concepts, apply them, relate them to other concepts that are the same/ different, use them to solve problems critically in students' lives in the context of real experiences".

Furthermore, HOTS questions are assessments based on real situations in daily life, students are expected to apply learning concepts in class to solve problems. Contextual problems faced by the world community today must be related to the environment, health, earth and space, as well as the use of science and technology in various aspects of life.

(G2, SMA1) "in the process of assessing student learning outcomes skills by relating (relate), interpreting (interprete), applying (apply) and integrating (integrate) knowledge in classroom learning to solve problems 
in real contexts. It means learning from the phenomena of student life in society".

Assessment can be based on contextual problems with characteristics: students construct their own responses, it does not merely choose the available answer; tasks are challenges must be faced in the real world; and assignments do not only have one particular answer that is correct, but it allows many correct answers or all correct answers. Based on the data that the things the teacher does in compiling the questions.

(G2, SMA3), it really needs to be considered in compiling questions: (1) analyzing the KD oriented HOTS questions; (2) arranging the questions in accordance with the CPI, the subject matter related to $\mathrm{BC}$ that will be tested, formulating the problem indicators, determining the cognitive level, determining the form of questions and number of questions, and choosing interesting and contextual stimuli; (3) writing question items according to the problem grid; (4) creating scoring guidelines (rubrics) or answer keys. Every HOTS item written should be accompanied by a scoring guideline or answer key. Scoring guidelines are made for the form of description items. In the complete question Indicator contains of $\mathrm{ABCD}$ components, namely Audience (students), Behavior (ability to be measured), Condition (stimulus), and Degree (degree of accuracy)". namely:

Likewise with data from other teachers,

(G1, SMA4) "All knowledge assessment activities are measured by paying attention to the $\mathrm{ABCD}$ instructor, for example writing a cognitive part of the text, filled with reasoning (including the dimensions of the process of analyzing thinking (C4), evaluating (C5), and creating/ creation (C6); part of the form of questions, filled with brief contents, or descriptions, but it still pay attention to the dimension of its characterization".

\section{Discussion}

\section{Designing the HOTS-Oriented Indonesian Language Learning}

The findings based on the focus of this research are HOTS-oriented Indonesian learning includes of designing, implementing, and evalu- ating HOTS-oriented Indonesian learning. The findings from the research show that teachers have a positive perception of HOTS-oriented Indonesian learning and the importance of HOTS for students' success in learning Indonesian. It is in line with the research results of Sulaiman, et al. (2017) teachers realize that HOTS needs to be incorporated into the learning process to improve achievement students and for the achievement of learning objectives.

In designing HOTS-oriented Indonesian language learning, teachers design learning using Minister of Education and Culture Regulation Number 20 Year 2016. Connecting each learning phase starting from understanding and analyzing Graduates Competency Standards (SKL, Core Competencies (KI), Basic Competencies (KD), and Indicators of Competency Achievement (GPA) In formulating GPA, teachers use operational verbs in accordance with Bloom's taxonomy, analyze (C4), assess (C5), and create (C6) that reflects HOTS.

The development of the materials is based on KD. The development of these materials in detail is adjusted to the characteristics of thinking competencies that are expected to emerge and be mastered by students, including 21 st century skills. The teacher has paid attention to the initial competencies students have as thinking stages that have been studied by students before. Furthermore, the teacher has also paid attention to the content or content of material in the form of factual, conceptual, procedural, and metacognitive knowledge.

Development of content/ learning materials/ materials has noticed to mandatory textbooks and other sources, materials are related to local content, both current material, interdisciplinary material or transdisciplinary material, material can be actualized in the daily lives of students. Present material is material that is being the topic of discussion relating to the surrounding environment and relevant to the competencies that students must master. Interdisciplinary material is material in a subject that has concepts related to other learning; whereas transdisciplinary material is material in a subject that has a concept or principle related to its application in real life. The concept has been used by the teacher to compile negotiating texts, for example, the teacher links several aspects, namely learning 
resources, tools or media used as found in the lesson plans designed by the teacher.

The teacher has also designed a method of learning based on text (genre based instruction), which is learning oriented to the ability of students to compose text. Indonesian language learning is conducted by teachers has referred to four text-based Indonesian learning syntaxes based on the Ministry of Education and Culture in 2013 and it is in line with research by Dewantara, Sutama, \& Wisudariani (2019) (1) in building context, teachers build unders-tanding students, (2) the modeling stage, the text modeling strategy in writing consists of three stages, namely reading the model text, analyzing the model text, and practicing writing by imitating the construction of the model text, (3) the stage of making text together, and (4) making text independently. This learning method is based on text modeling and analysis of its features expli-citly and focuses on the relationship between the text and the context of its use. The design of the learning units leads students to be able to unders-tand and produce texts both oral and written in various contexts. For this reason, students need to understand the social functions, structure, and linguistic features of texts. In addition, the teacher has strengthened the character-oriented ability to think critically, the ability to communicate, res-pect the opinions of others, be confident, and in-fluence others through the procedure of argumen-tation so that they can defend their arguments.

\section{Implementing HOTS-Oriented in Learning Design}

\section{Pre-Activities}

The activities carried out by the teacher and students in starting the learning are as follows: (a) the initial activities carried out by the teacher say hello and students respond as a sign or a form of thanksgiving for life and language learning as a gift from God and do prayer reading at the beginning of learning while instilling religious (religious values), (b) the teacher explains and relates previous learning in the form of questions, statements or conclusions accompanied by several questions to motivate students to begin learning, (c) students seriously and critically respond to questions are raised by the teacher about the material that has been and will be studied, (d) students critically listen to the infor- mation given by the teacher about Core Competencies (KI), Basic Competencies (KD), Competency Achievement Indicators (GPA), learning objectives to be achieved, characterization (character values) to be implemented in real student life, (e) students discuss information proactively about the relationship of previous learning information with learning to be learned (communicating and working together), (f) students actively respond to information given by the teacher about the things being learned, the teacher prepares media or teaching aids, learning scenarios, tools evaluation and enrichment material.

\section{Whilst Activities}

Building knowledge of the students was conducted by orienting the students to the cognitive domain that contains factual knowledge and basic elements that should be understood by the students in solving a problem. The elements are usually symbols that relate to some concrete references that convey important information. The first is factual knowledge, terminology knowledge includes certain verbal and non-verbal names and symbols (for example words, numbers, signs, and images). Second, detail knowledge and specific elements refer to knowledge of events, places, people, dates, sources of information.

\section{Post-Activities}

In closing the ideal learning, the teacher must do several things including raising students' responsive actions in making a summary/ conclusion or reflection on learning; carrying out the assessment properly; responding sincerely to the assignments given by the teacher.

In designing Indonesian language learning is oriented to HOTS, teachers design learning materil is accordance with Minister of Education and Culture Regulation No. 20 of 2016 concerning Competency Standards for Primary and Secondary Education Graduates. Connecting each learning phase starts from the understanding and analysis of Graduates Competency Standards (SKL, Core Competencies (KI), Basic Competencies (KD), and Competency Achievement Indicators (GPA). C4), assess (C5), and create (C6) that reflects HOTS, Bloom's taxonomy is also a teacher's reference for assessing HOTS learning.

However, the application in the field of teachers only uses one approach, for example 
teachers use a scientific approach using only inquiry methods, in fact, teachers can use more than one method. The teacher should integrate the three approaches, (1) genre of pedagogy, (2) scientific, and (3) CLIL in order to KD can be achieved. This becomes a challenge or obstacle for teachers in Indonesian learning which must be oriented into HOTS . In line with the research of Seman, Yusoff, \& Embong (2017), the obstacles faced by teachers in HOTS-oriented learning are in the fields of planning, achievement of objectives and learning outcomes. Teachers feel that they need more time to be able to plan their lesson plans to achieve the HOTS goals. Teacher's efforts in using strategies, methods, and Indonesian learning are oriented into HOTS can be said that the teacher has tried to direct students to think critically and creatively, (Bishop, Caston, \& King, 2014); (Warmadewi, Agustini, \& Wedhanti, 2019). Certainly, the purpose of using strategy, method, approach, and learning media is to implement Indonesian language learn-ing HOTS oriented.

\section{Evaluating Students' Performance in HOTS- Oriented Learning}

The evaluation done by the teacher is learning dimension orientation experienced by students to create (1) attitude and perception; the teacher plays the role of assisting the students to develop positive attitude with the feeling of acceptance from teacher, peers, self confidence, meaningful, and trust on solving the task independently; (2) obtain and integrate the knowledge by helping the students to get declarative knowledge with instruction, saving, developing procedural knowledge by internalizing it into students' daily life; (3) enlarge and trawl knowledge by assisting the students to develop complex reasoning process and doing comparison, classification, construction, and analysis; (4) use the knowledge meaningfully by making decision, problem solv-

\section{REFERENCE}

Aryana. (2018). Pembelajaran yang Berorientasi HOTS. Jakarta: Gramendia.

Bishop, C. F., Caston, M. I., \& King, C. A. (2014). Learner-Centered Environments: Creating Effective Strategies Based on Student Attitudes and Faculty Reflection. Journal of the Scholarship of Teaching and Learning, 14 (3): 46-63. ing, and discovery; (5) and thinking behavior, is helping the students to be able of productively think critically such as accuracy, clarity, open thought, placing themselves in the right situation. The assessment done by the teacher referring to Bloom Taxonomy such as analyzing (C4), assessing (C5), and creating (C6) (Merta Dhewa, Rosidin, Abdurrahman, \& Suyatna, 2017); Serevina, Sari, \& Maynastiti, 2019). Certainly these are done by teacher to measure students' critical thinking ability in accordance with students' level of thinking.

\section{CONCLUSION}

The results of the analysis showed that the Indonesian Language teachers were able to design and implement the HOTS-oriented Indonesian Language learning. They were also able to implement the model in the classroom and evaluate students' performance. Unfortunately, the teachers failed to integrate the concept of genrebased learning and Content and Language Integrated Learning (CLIL) into the model.

Therefore, it is suggested that the Indonesian Language teachers should first improve their understanding of HOTS so that they can design, implement, and evaluate learning based on HOTS, as is mandated by Dirjen GTK 2018. Besides that, the teachers also need to understand the content mentioned in Dirjen PSMA 2017 about the guideline of the 2013 Indonesian Language Learning Curriculum and The Regulation of Ministry of Education and Culture No. 66 in 2013 about The Standard of Educational Assessment.

In accordance with the explanation above, the future researchers are expected to conduct research related to other designs and implementations of the HOTS-oriented Indonesian Language learning. It is also important to analyze various assessment models in the HOTS-oriented Indonesian language learning classrooms.

Creswell, J.W. (2009). Qualitative Inquiri and Research Design: Cloosing Among Five Approaches. Edisi 2. Thousan Qoks. CA Sage.

Dewantara, A. B. J., Sutama, I. M., \& Wisudariani, N. M. R. (2019). Pembelajaran Bahasa Indonesia Berbasis Teks di SMA Negeri 1 Singaraja. 
Jurnal Pendidikan Bahasa dan Sastra Indonesia Undiksha, 9 (2).

Dinni, H. N. (2018). HOTS (High Order Thinking Skills) dan Kaitannya dengan Kemampuan Literasi Matematika. In PRISMA, Prosiding Seminar Nasional Matematika, 1: 170-176.

Dirjen PSMA (2017). Panduan Pembelajaran Bahasa Indonesia Kurikulum 2013. Jakarta.

Dirjen GTK (2018). Pegangan Guru dalam Pembelajaran yang Berorientasi Berpikir Tingkat Tinggi. Jakarta.

Gunawan, I., \& Palupi, A. R. (2016). Taksonomi Bloom-Revisi Ranah Kognitif: Kerangka Landasan untuk Pembelajaran, Pengajaran, dan Penilaian. Premiere Educandum: Jurnal Pendidikan Dasar dan Pembelajaran, 2 (2): 98117.

Kemendikbud. (2013). Salinan Lampiran Peraturan Menteri Pendidikan dan Kebudayaan Nomor 66 Tahun 2013 tentang Standar Penilaian Pendidikan.

Kemendikbud. (2016). Salinan Lampiran Peraturan Menteri Pendidikan dan Kebudayaan Nomor 20 Tahun 2016 tentang Standar Kompetensi Lulusan Pendidikan Dasar dan Menengah.

Norman K. \& Tvona S. Lincoln (2009). Handbook of Qualitative Research. Diterjemahkan oleh Dariyatno dkk. Yogyakarta: Pustaka Pelajar.

Lincoln, Yonna S. \& Egon G. Guba. (1997). Naturalistic Inquiry. Beverly Hills: Sage Publications.

Mahsum. (2014). Teks dalam Pembelajaran Bahasa Indonesia Kurikulum 2013. Jakarta: Raja Grafindo Persada.

Merta Dhewa, K., Rosidin, U., Abdurrahman, A., \& Suyatna, A. (2017). The Development of Higher Order Thinking Skill (HOTS) Instrument Assessment in Physics Study. IOSR Journal of Research \& Method in Education (IOSR-
JRME), 7(1): 26-32.

Pamungkas, N. A. R. (2019). Penerapan Higher Order Thinking Skills (HOTS) untuk Meningkatkan Keterampilan Membaca Siswa SMA. Tajdidukasi: Jurnal Penelitian dan Kajian Pendidikan Islam, 8 (1): 127-141.

Rurisfiani, A., Ramly, \& Sultan. (2019). Level Berpikir Pertanyaan Guru pada Pembelajaran Bahasa Indonesia. Bahasa: Jurnal Keilmuan Pendidikan Bahasa dan Sastra Indonesia, 1 (2): 111-119.

Seman, S. C., Yusoff, W. M. W., \& Embong, R. (2017). Teachers Challenges in Teaching and Learning for Higher Order Thinking Skills (HOTS) in Primary School. International Journal of Asian Social Science, 7 (7): 534-545.

Serevina, V., Sari, Y. P., \& Maynastiti, D. (2019). Developing High Order Thinking Skills (HOTS) Assessment Instrument for Fluid Static at Senior High School. In Journal of Physics: Conference Series, 1185 (1): 012034). IOP Publishing.

Sulaiman, T., Muniyan, V., Madhvan, D., Hasan, R., Syrene, S., \& Rahim, A. (2017). Implementation of Higher Order Thinking Skills in Teaching of Science: A Case Study in Malaysia. International Research Journal of Education and Sciences (IRJES), 1 (1): 2550-2158.

Warmadewi, P. S., Agustini, D. A. E., \& Wedhanti, N. K. (2019). Analysis of Learning Higher Order Thinking Skill (HOTS) toward English Subject. Jurnal Penelitian dan Pengembangan Sains dan Humaniora, 3 (2): 134-140.

Woodside, A. G. (2010). Case Study Research: Theory, Methods and Practice. Wagon Lene, Bingkey.

Yin, R.K. (2003). Case Study Research: Design and Methods. (2 ${ }^{\text {nd }}$ ed.) Thousand Oaks, CA: S 